\title{
Persistence and Survival of Dried Sperm DNA under Ambient Conditions
}

\author{
Lay-Hong Seah* and Boon-Hui Wee \\ Department of Chemistry Malaysia, Kuching branch
}

Submission: March 26, 2017; Published: March 30, 2017

*Corresponding author: Lay-Hong Seah, Department of Chemistry Malaysia, Kuching branch, Lot 3148, Block 14, Jalan Sultan Tengah, 93050 Petra Jaya, Kuching, Malaysia, Tel: (60)082-313011; Email: lhseah@kimia.gov.my

\begin{abstract}
The survival of sperm DNA in semen stains could be attributed by the resilient, protective structure of the sperm head which enables DNA in the sperm nucleus to survive for prolonged periods of time. The separation profiles of sperm DNA mixtures by differential extraction are peculiar only to sperm cells and thought to be associated with the intrinsic properties of semen. Experiments with dried semen on fabric stored under ambient conditions tested over a period of nine months (realistic maximum time for forensic casework submission) demonstrated the persistence and survival of sperm DNA with no allelic or locus dropouts. The separation profiles of sperm mixtures in the aging experiments detected no variations in the separation patterns of major-minor mixtures underlining the reliability of dried aged semen stains for interpretation in forensic casework.
\end{abstract}

Keywords: Sperm DNA; Semen; Differential extraction; DNA interpretation; DNA survival; Aged semen stain

\section{Introduction}

The persistence of sperm DNA in semen stains is associated with the extraordinary resistance to disruption by the sperm nucleus with a significant complement of -S-S- cross-links within the chromatin [1,2]. The extreme degree of disulfide bonding in the sperm chromatin confers on the sperm nucleus a resistance to environmental ravages, thus permitting sperm DNA to remain readable over an extended period of time. The disulfide bonding in the sperm chromatin forms the basis of the differential extraction procedure [3] for separation of DNA types in semen stains. It has been noted that differential extraction of sperm mixtures deconvolutes the mixture [4], a phenomenon not observed with mixtures of other cell types [5]. Hence, it is thought that the intrinsic properties of semen played a role in the separation during differential extraction. These intrinsic properties could be from the constitution of the seminal fluid or the cellular make-up of sperm chromatin. Six different sperm mixtures of semen dried on white polyester-viscose cloth comprising of a major and minor contributor(s) stored under ambient conditions were examined over a period of 9 months at 3-monthly intervals. This was intended to study the consequent effects of 'aging' on the properties of semen which were expected to impact on the differential profiles of the sperm mixtures and subsequent interpretation of the DNA results

\section{Method}

The methodology was as described by L.H. Seah and B.H Wee $[4,5]$. The DNA was examined using the AmpFISTR $\AA$ Identiler Plus amplification kit for 28 cycles according to manufacturer's instructions.

\section{Results and discussion}

Four similar sets of six different sperm mixtures comprising of a major and minor contributor(s) were set up (Table 1). DNA estimates were from quantification of discs punched from the semen stained cloth. The four sets were analyzed at three monthly intervals and defined respectively as 0 -mth, 3-mth, 6-mth and 9-mth. The 9-month period was assumed to be a realistic maximum time frame that forensic casework of a sexual assault type could be submitted to a forensic DNA laboratory. When the DNA differential profiles for the six mixtures were assessed over the time periods studied, no variations were detected over the 9-month period. The differential profiles indicated the same separation patterns and no allelic or locus dropouts were observed in any of the non-sperm or sperm extracts when compared over the 9-month period. Clearly, the integrity of dried sperm DNA is preserved under ambient storage conditions over a period of months. The persistence and survival of dried sperm 
DNA is important and relevant to forensic casework applications and represents an assurance that interpretation of aged semen stains remain reliable. Further work may be required to elucidate the mechanisms and biochemical properties in semen that helps protect the integrity and behavior of semen DNA.

Table 1: Sperm mixtures comprising of a two-source major-minor in mixtures 1 to 4 and a three-source major-minors in mixtures 5 and 6 .

\begin{tabular}{|c|c|c|c|c|}
\hline No. & Semen (DNA) Mixture & $\begin{array}{c}\text { Non-sperm extract } \\
(0,3,6,9-\mathrm{mth})\end{array}$ & Sperm Extract $(0,3,6,9-m$ th $)$ & Allelic / Locus dropouts $(0,3,6,9-\mathrm{mth})$ \\
\hline 1 & $\begin{array}{l}\text { Major (M1) } 107 \mathrm{ng}+\text { Minor } \\
\text { (M2) } 9 \mathrm{ng}[\mathrm{M} 1] 12:[\mathrm{M} 2] 1\end{array}$ & $\begin{array}{c}\text { M1 + M2 } \\
\text { M1 = major }\end{array}$ & $\begin{array}{c}\text { M1 = dominant } \\
\text { M2 = not reportable* }\end{array}$ & No allelic/locus dropout \\
\hline 2 & $\begin{array}{l}\text { Major (M1) } 107 \mathrm{ng}+\text { Minor } \\
\text { (M2) } 18 \mathrm{ng}[\mathrm{M} 1] 6:[\mathrm{M} 2] 1\end{array}$ & $\begin{array}{c}\text { M1 + M2 } \\
\text { M1 = minor }\end{array}$ & $\begin{array}{c}\text { M1 = dominant } \\
\text { M2 = not reportable* }\end{array}$ & No allelic/locus dropout \\
\hline 3 & $\begin{array}{l}\text { Major (M1) } 107 \text { ng + Minor } \\
\text { (M3) } 8 \text { ng [ M1] } 13: \text { [M3] } 1\end{array}$ & $\begin{array}{c}\mathrm{M} 1+\mathrm{M} 3 \\
\mathrm{M} 1=\text { minor }\end{array}$ & $\begin{array}{c}\text { M1 = dominant } \\
\text { M3 = not reportable* }\end{array}$ & No allelic/locus dropout \\
\hline 4 & $\begin{array}{l}\text { Major (M1) } 107 \mathrm{ng}: \text { Minor } \\
\text { (M3) } 16 \mathrm{ng}[\mathrm{M} 1] 7:[\mathrm{M} 3] 1\end{array}$ & $\begin{array}{c}\text { M1 + M3 } \\
\text { M1 = minor }\end{array}$ & $\begin{array}{c}\text { M1 = dominant } \\
\text { M3 = not reportable* }\end{array}$ & No allelic/locus dropout \\
\hline 5 & $\begin{array}{l}\text { Major (M1) } 280 \mathrm{ng}+\text { Minor } \\
\text { (M2) } 57 \mathrm{ng}+\text { Minor (M3) } 9 \mathrm{ng} \\
\text { [M1] } 31:[\mathrm{M} 2] 6.3:[\mathrm{M} 3] 1\end{array}$ & $\mathrm{M} 1+\mathrm{M} 2+\mathrm{M} 3$ & $\begin{array}{c}\text { M1 = major } \\
\text { M2 = minor } \\
\text { M3 = not reportable* }\end{array}$ & No allelic/locus dropout \\
\hline 6 & $\begin{array}{l}\text { Major (M1) } 280 \mathrm{ng}+\text { Minor } \\
\text { (M2) } 57 \mathrm{ng}+\text { Minor (M3) } 25 \mathrm{ng} \\
\text { [M1] } 11:[\mathrm{M} 2] 2.3:[\mathrm{M} 3] 1\end{array}$ & $\begin{array}{c}\mathrm{M} 1+\mathrm{M} 2+\mathrm{M} 3 \\
\mathrm{M} 3 \text { = major }\end{array}$ & $\begin{array}{c}\text { M1 = major } \\
\text { M2 = not reportable* } \\
\text { M3 = not reportable* }\end{array}$ & No allelic/locus dropout \\
\hline
\end{tabular}

*Not reportable $=$ insufficient allelic information for conclusive interpretation

\section{Acknowledgement}

My special thanks to the staff of the Department of Chemistry, Malaysia, Kuching DNA Laboratory for technical assistance and support. This project is funded by Ministry of Science, Technology and Innovation Malaysia science fund project No: 02-05-10-SF0009.

\section{References}

1. Bedford JM, Bent MJ, Calvin H (1973) Variations in the structural character and stability of the nuclear chromatin in morphologically normal human spermatozoa. J Reprod Fert 33(1): 19-29.
2. Calvin HI, Bedford JM (1971) Formation of disulphide bonds in the nucleus and accessory structures of mammalian spermatozoa during maturation in the apididymis. J Reprod Fert Suppl 13: 65-75.

3. Gill P, Jeffreys AJ, Werrett DJ (1985) Forensic application of DNA 'fingerprints'. Nature 318(6046): 577-579.

4. Lay-Hong Seah, Boon-Hui Wee (2015) Separation Patterns of Semen Mixtures: The Major-Minor Impact. Forensic Science International: Genetics Supplement Series 5: e582-e583.

5. LH Seah, BH Wee (2016) Jacobs. Journal of Forensic Science 2(2): 13.

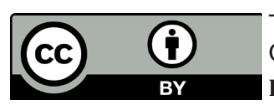

This work is licensed under Creative Commons Attribution 4.0 License DOI: $10.19080 /$ JFSCI.2017.02.555599

\section{Your next submission with Juniper Publishers will reach you the below assets}

- Quality Editorial service

- Swift Peer Review

- Reprints availability

- E-prints Service

- Manuscript Podcast for convenient understanding

- Global attainment for your research

- Manuscript accessibility in different formats

( Pdf, E-pub, Full Text, Audio)

- Unceasing customer service

Track the below URL for one-step submission https://juniperpublishers.com/online-submission.php 